\title{
Correction to: Delineation of potential hot spots of aeolian dust using normalized difference water index
}

\author{
Chao-Yuan Lin ${ }^{1}$. Shu-Fen Tsai ${ }^{1} \cdot$ Chih-Yun Wang ${ }^{1} \cdot$ Cheng-Yu Lin ${ }^{2}$ (D)
}

Published online: 5 May 2021

(C) Springer-Verlag GmbH Austria, part of Springer Nature 2021

\section{Correction to: Theoretical and Applied Climatology https://doi.org/10.1007/s00704-021-03611-2}

The original version of this article unfortunately contained a mistake. During the production process, the authors' information had been inadvertently changed. The country name should read "Taiwan, Republic of China".

The original article has been corrected.

Publisher's note Springer Nature remains neutral with regard to jurisdictional claims in published maps and institutional affiliations.

The online version of the original article can be found at https://oi.org/ $10.1007 / \mathrm{s} 00704-021-03611-2$

Cheng-Yu Lin

dgjkpsz@gmail.com

1 Department of Soil and Water Conservation, National Chung Hsing University, Taichung, Taiwan, Republic of China

2 Corporate Environmental Protection Taiwan Environmental Greening Association, Taichung, Taiwan, Republic of China 